\title{
The Artistry and Function of Gift Paper*
}

\author{
Yan Zhou \\ Zhuhai College of Jilin University \\ Zhuhai, China 519041
}

\begin{abstract}
Gift paper is a modern paper craft form that combines the characteristics of both Chinese and foreign paper materials. It has a classic flavor of history and culture and can show a lively and fresh modern dynamic atmosphere. Through the concise and clean design style, the gift paper shows a kind of ancient charm long and fresh Oriental charm, giving full play to its function and artistic nature.
\end{abstract}

\section{Keywords—gift paper; functionality; artistry}

\section{INTRODUCTION}

In the gift paper craft, the paper characteristic is remarkable, the printing technique is diversiform, the decoration element and the pattern are rich, having an extremely strong artistic esthetic quality. The gift paper technology has various uses and has many uses in daily life. It has been widely used in people's life and shows good functionality.

\section{FUNCTION OF GIFT PAPER}

Gift paper is an important packaging paper material in modern packaging technology, which can protect, package and decorate commodities. Moreover, gift paper materials can be recycled, which can be degraded and recycled, having a strong practical function.

\section{A. The Basic Function of Gift Paper Is to Protect the Perfect State of Gifts}

In modern packaging, gift paper can play a protective role in commodities, to a certain extent, to prevent external forces from damaging commodities and protect the integrity of commodities. It can strengthen the ability of commodities to withstand external forces to help protect some vulnerable commodities. For example, the gift paper packaging of confectionery, proportion crystal products and other commodities has the function of blocking external forces to a certain extent. Some oil, moisture, sun protection paper can block sunlight and prevent damp environment to have impact on the quality of the goods, to protect the special qualified goods from the effects of the external environment. For example, gift paper packaging for nuts, perfume, lipstick, etc. The protective function of ritual paper plays an important role to ensure product quality. In the application of the gift paper, we should determine the material and modeling of the paper according to the nature of the commodity, and use paper to protect the goods and to ensure the quality of integrity and

*Guangdong social science foundation project: Guangdong province advertising major comprehensive reform pilot project No. 2014009. quality of the goods.

\section{B. Performance of Gift Paper in Decoration Function}

In recent years, with the increasing application of gift paper in commodity packaging, more and more merchants are willing to integrate gift paper materials into commodity packaging. The variety of texture and printing techniques of gift paper materials can show many different styles and characteristics. It can show more beautiful commodity lasting appeal, bring people fresh commodity image, promote the unique value of commodity and bring people more vivid and three-dimensional commodity image. The application of gift paper has played the role of decoration and embellishment on commodities. Some gift paper packaging can even become a part of commodities, fully showing the uniqueness and charm of commodities. For example, the packaging gift paper of creative flower bouquets, through the unique creative modeling, sets off the lively and fresh flowers, and displays a unique flavor of alternative beauty. It triggers people's new thinking on the quality and taste of commodities and endows them with more personalized brand image, makes the product stand out from the competition of the same kind of product, brings the vivid market image of the product and deepens the impression of the product in the consumers' mind.

\section{Gift Paper and Environmental Values and Diverse Practicality}

Gift paper is a creative and unique packaging form in modern commodity packaging. Packaging bearing the decoration function and ability to not only protect the goods, but also reflect a modern way of life and environmental protection concept, bringing people a more modern way of life and development. The material of gift paper is diversified and has rich forms, and some of them are not environment-friendly due to oil printing and other reasons. However, with the deepening of the concept of healthy life in people's mind, environmental protection has become more and more practical in the packaging design of gift paper. For example, designers use gift paper to make delicate and strong packaging design to attract consumers to use diversified packaging, which reduces the direct discard rate of packaging. It is the product packaging after completing a functional task to acquire more personalized new functions, so that a design can obtain multiple opportunities for use. It has been welcomed by people and realized the goal of energy conservation and emission reduction with a more modernized and interesting idea. 


\section{THE ARTISTRY OF GIFT PAPER}

\section{A. Artistic Quality of Material Selection Printing}

Gift paper has a unique flavor among the paper type. The material choice is different from the beginning to the end and it can show a different taste and breath. Different packaging products adopt different gift paper design, which can show unique visual characteristics. The material selection of gift paper can highlight the characteristics of commodities, show the value and aesthetic taste of commodities and promote commodities to bring more prominent sensory impressions to people. The printing of gift paper enriches the layering and thickness of gift paper and gives people a diversified visual impression. For example, hot stamping process, laminating, UV metal etching proof printing process, etc., such printing process has an important influence on the artistic quality of gift paper, making gift paper's texture more outstanding and more delicate. And some gift paper uses concave and convex printing techniques to enhance the texture of the design. Through the concave and convex image of the paper, it presents the three-dimensional nature of the gift paper. And with the three-dimensional shape and concise color, it endows the gift paper with more artistic content. So that the gift paper can better cater to the artistic flavor of commodities and bring people the enjoyment of beauty.

\section{B. The Artistry of the Pattern Style}

With the continuous development of gift paper in China, the pattern of gift paper is also enriched. The pattern change of the gift paper caters to the change of public taste. The content of pattern is becoming more and more diversified and the artistic quality of pattern is becoming more and more intense. The application of many distinctive patterns in the art of gift paper adds a diversified artistic flavor to the art of gift paper. For example, the gift paper with the gentle and refined style of Japanese has a strong flavor of life and sentiment, a very high aesthetic value and has won people's love. Another example, fragrant and simple and unsophisticated ancient Chinese style paper patterns, wrapped with the thick Chinese culture and long ancient hieroglyphic patterns, shows people he accumulation of ancient totem of the Chinese nation culture, bringing commodities ancient customs. For another example, some gift paper designs in western countries have strong and lively colors and flexible patterns. The pattern of gift paper presents a different artistic style and gives people a strong aesthetic experience. And it is these diversified patterns that constitute the modern art style of gift paper, making the contemporary gift paper more artistic.

\section{The Artistry of Gift Paper Packaging}

The artistry of modern gift paper is not only reflected in the printing and pattern design of gift paper itself, but also in the packaging design and modeling of gift paper. In the packaging of gift paper, the design of gift paper, the pattern of gift paper and the use of packaging combine together to form a characteristic gift paper packaging art. For example, some products with special shapes are packaged in different shapes, such as circles, squares, diamonds and other more complex shapes. The paper combines the characteristics of the product modeling, embodying the culture and artistic quality of paper. At the same time, it highlights the visual impact of gift paper, its image more prominent, characteristics more brilliant, thus being more artistic.

\section{COMPREHENSIVE APPLICATION OF ART AND FUNCTION} OF GIFT PAPER

\section{A. The Patterns and Colors of Gift Paper Highlight the Features of Commodities}

In the design of gift paper, gift paper pattern and color are the most important part of commodity packaging design, an important element of highlighting the characteristics of goods and the special elements the designers have to pay special attention to in commodity packaging design. Product packaging designers should highlight the characteristics of products through color and pattern elements in the design process. For example, in candy packing design, the color and pattern of paper should be given priority to a pure, fresh and lively style, showing a clever and relaxed atmosphere, bringing customers lots of joy in the sensory, enhancing the rendering of the characteristics of the product. Some creative products with artistic temperament, such as stationery combination set, aromatherapy, round fan and other products should be paid more attention to the texture and artistry of packaging. Through simple colors and artistic logo design, as well as textured gift paper printing and pattern style, the packaging design with texture and artistic flavor is brought to consumers. As a result, it highlights the artistic features of products, attracts the attention of target consumers and strengthens the characteristics of products, thus attracting the attention of consumers.

\section{B. The Function of Gift Paper Is Strengthened in the Design}

In gift paper design, functional features should be further strengthened in the process of highlighting artistic nature, making the function of the gift paper further penetrated in the design and showing its the functional characteristic through an art form with a stronger sense of life. For example, in the packaging design of traditional Chinese food mooncakes, the use of gift paper packaging design shows the ancient Chinese cultural aesthetic taste, the use of circular packaging design shows the meaning of reunion and peace in Chinese culture. At the same time, it plays the role of packaging to protect goods from bumps, making the gift paper packaging of mooncakes with both artistic beauty and practical packaging to stimulate consumer demand for purchase.

\section{The Artistry and Functionality of Gift Paper Complement Each Other}

In the design of gift paper, the artistry and functionality of gift paper are extremely important. The principle of combining design artistry and functionality should be followed in the design process. In the process of design, the artistry and functionality of design should be combined as much as possible, so that the two can complement each other and achieve the perfect combination of artistic aesthetics and functional practicality. For example, in the packaging design of nut gift paper, we combine the packaging design of gift 
paper with environmental protection and turn the used gift paper packaging into a fruit skin receiving box, which gives consideration to both the beauty and practicality of gift paper. It will bring more practical value to the gift paper packaging and enhance its practicality.

\section{CONCLUSION}

In a word, in the process of packaging design of gift paper, the principle of integrating both functional and artistic features should be followed. We should constantly introduce fresh train of thought and ideas in the design, combined with the essence of Chinese and foreign ritual paper design, take the tolerance design idea to bring gift paper richer aesthetic feeling and practicability of the new way of thinking, improve the practical value of the gift paper packaging, bringing more unique charm to the gift paper packaging and giving it more vitality in the process of development.

\section{REFERENCES}

[1] Zhang Qingfeng. Tea packaging design [D]. Nanchang University,2013. 张清风. 茶包装设计[D].南昌大学, 2013 .

[2] Huang Hao. Research on packaging design of Chinese cigarettes [D]. Zhongnan University of Forestry and Technology,2013. 黄浩. 中式香 烟包装设计研究[D].中南林业科技大学, 2013 .

[3] Wen Honglin. On China's packaging design innovation [D]. Tianjin University of Technology,2006. 文红林. 论中国包装设计创新[D].天 津工业大学,2006. 